\title{
Perception of Sheep and Goat Milk Consumption among Rural Dwellers in
} South-Western Nigeria

*Apata, O.M. and ** O.O. Adewumi

*Department of Agricultural Economics and extension Services, University of Ado-

Ekiti, Ekiti State, Nigeria. simboapata@yahoo.com 234+8034115433

** Department of Animal Production and Health University of Abeokuta,

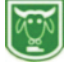

Ogun State, Nigeria.

\begin{abstract}
A total of 120 respondents were purposively selected to study the perception of sheep and goat milk consumption among rural dwellers in South-Western Nigeria. The study showed that most of the respondents $(72.5 \%)$ are not aware of the consumption of such milk and as such only few $(10,8 \%)$ claimed that they have consumed it. Friends, relatives $(14.2 \%)$ and health personnel (6.7\%) were the sources of information on goat and sheep milk consumption to the respondents. Preference of other sources of milk, lack of awareness, traditional belief, odour of the milk and small quantity of the milk were the factors that discourage people from consuming the milk. Many of the respondents (57.7\%) have positive perception of the milk. Among the socio-economic characteristics, age ( $r=$ $0.58417,0.0001)$, educational qualification $\left(X^{2}=25.584, p<0.05\right)$, marital status $\left(X^{2}=\right.$ 131.87, $p<05)$ and family size $(r=0.98751, p<0.05)$ have significant relationships with the perception of the respondents about the milk.
\end{abstract}

Key: Goat and Sheep milk, consumption, perception, rural dwellers and animal protein

\section{Introduction}

Currently, Nigeria is facing an acute shortage of all types of food including milk despite the fact that the Nigerian government is spending huge foreign exchange on importation of various brands of dairy products. Milk has been one of the earliest diets for human beings and other mammals. Its protein represents one of the most important sources of essential amino-acid for human beings (Mohammed and Mohammed, 1989). Over the years, milk consumption is on the decline in Nigeria. The declining production and increasing demand has led to importation of this important protein source. However, it is not all the citizens that can afford the cost of purchasing the imported milk, thus causing the prevalence of various forms of animal
Protein and caloric malnutrition diseases such as kwashiorkor and irreversible brain damage leading to intellectual dwarfism which is common among the vulnerable groups such as weaning, preschool age, expectant mothers and nursing mothers (Aletor, 1983)

The major reason why Nigeria cannot produce her milk requirement is her acceptance of cow as the only dairy animal while sheep and goat are kept for the production of meat, hides and skin. Sheep and goat produce more milk in relation to body weight compared with cows. They are easier to handle and maintain than the large ruminants and the land requirement as well as capital expenditure to produce sheep is low. They produce more offspring and have a 
gestation length of 5 months in a single year whereas this is not possible for the cow. Moreover, less is spent on medication as the sheep are resistant to most endemic diseases in the tropics. Wilson (1984) reported that almost every household keeps sheep and goat in most rural areas in Nigeria.

Sheep milk has been found to be of higher nutritive value which contains some important nutrients such as protein, calcium, iron, magnesium, zinc, thiamine, riboflavin, vitamins $\mathrm{B}_{6}, \mathrm{~B}_{12}, \mathrm{D}$, medium chain fatty acids (which limits cholesterol deposition), monounsaturated acids, linolenic acid and all 10 essential acids than that of human, cattle and goat in all respects except in lactose and is bacteriologically sterile (Bufano et al., 1996, Park et al. 2007). The high constituent of Vitamin D and calcium in sheep milk help in fighting against osteoporosis. The milk of sheep has laxative properties and is about 50 percent richer in vitamin B than cow's milk which makes it very useful in the treatment of neurotic indigestion, insomnia and rheumatism. It also has greater digestibility and can be prescribed practically for all cases of dyspepsia, peptic ulcer and pyloric stenosis. It is better tolerated by infants at weaning or children liable to fat intolerance or acidosis due to the easier breakdown of fat globules (Daniluk, 2007). It can be used to treat bedwetting in children and older people. It is also for treatment of asthma, skin, and lung disorders and eczema because of high constituent of calcium and zinc. There is increased flavour in yoghurt and cheese (Park et al. 2007) prepared using sheep milk. Sheep are better converters of carotene to vitamin A and the amount of vitamin A in the adult sheep is twice that of cow milk. Riboflavin is higher in small ruminants even when both classes of animals are maintained on comparable diets and are also reported to transfer vitamin $\mathrm{E}$ into their milk more readily. Sheep and goat milk have been proposed as a more natural and better tasting alternative, with great nutritional and clinical potential (Adewumi et al. 2001). Sheep and goat milk can be processed into cheese, butter and yoghurt.

Sheep milk is not produced and utilized on commercial scale in Nigeria (Adewumi et al. 2001). Unlike some African countries such as Sudan, Algeria, Mali and Niger where the bulk of their milk production is from goat and sheep, sheep milk remains the most untapped resource in Nigeria livestock industry ( FAO, 1998). Considering the low socioeconomic status of rural households who cannot afford to consume recommended quantity of animal protein, sheep and goat milk consumption can be used to improve their animal protein intake in a very cost effective manner. This study was designed therefore to examine the awareness and perception of rural households on sheep and goat milk consumption in South-western Nigeria.

\section{Materials and Methods}

The study was conducted among sheep and goat farmers in the South-western region of Nigeria. Simple random sampling procedure was used to select two States (Ekiti and Osun) and the rural areas which were purposefully selected. This was based on the prominent involvement in goat and sheep rearing. Sixty respondents each were drawn from each of the two States making a total of one hundred and twenty (120) respondents. Both primary and secondary data were used. The primary data were obtained through a well structured and validated interview schedule and direct 
observation. The secondary data were obtained from journal, literature, mimeograph and relevant materials. Data were subjected to frequency count, percentages, mean, median standard deviation and correlation analysis.

\section{Result and Discussion}

The result of the analysis (Table1) shows that $32.5 \%$ of the respondents are below the ages of 30 years and only $12.5 \%$ are above 60 years. The mean age of the respondents was 39.76 years with standard deviation of 16.285 . This means that most of the respondents are in their energetic and reproductive age. This is an indication that the respondents are mature

\begin{tabular}{|c|c|c|}
\hline $\begin{array}{l}\text { Table1. Frequency Distribution of Socio } \\
\text { Characteristics of the Respondents }\end{array}$ & & \\
\hline \multirow{2}{*}{\multicolumn{3}{|c|}{ Age }} \\
\hline & & \\
\hline Below 30 years & 39 & 32.5 \\
\hline $31-40$ & 35 & 29.2 \\
\hline $41-50$ & 23 & 19.2 \\
\hline $51-60$ & 13 & 10.8 \\
\hline Above 60 & 10 & 8.3 \\
\hline \multicolumn{3}{|l|}{ Sex } \\
\hline Male & 65 & 54.2 \\
\hline Female & 55 & 45.8 \\
\hline \multicolumn{3}{|l|}{ Marital status } \\
\hline Single & 32 & 26.7 \\
\hline married & 81 & 67.5 \\
\hline divorced & 3 & 2.5 \\
\hline widowed & 5 & 3.3 \\
\hline \multicolumn{3}{|l|}{ level of education } \\
\hline no formal education & 30 & 25.0 \\
\hline Primary education & 13 & 10.8 \\
\hline Secondary education & 47 & 39.2 \\
\hline Post secondary education & 30 & 25.0 \\
\hline \multicolumn{3}{|l|}{ Primary occupation } \\
\hline Farming & 19 & 15.8 \\
\hline Trading & 39 & 32.5 \\
\hline Civil service & 25 & 20.8 \\
\hline Artisans & 16 & 13.4 \\
\hline Others & 21 & 17.5 \\
\hline \multicolumn{3}{|l|}{ Family size } \\
\hline $1-4$ & 47 & 39.2 \\
\hline $5-8$ & 52 & 43.3 \\
\hline Above 8 & 21 & 17.5 \\
\hline \multicolumn{3}{|l|}{ Religion } \\
\hline Christianity & 80 & 66.7 \\
\hline Islamic & 36 & 30.0 \\
\hline Traditional & 4 & 3.3 \\
\hline $\begin{array}{l}\text { Degree of cosmopolitani sm } \\
\text { Often }\end{array}$ & & \\
\hline Once in a month & 35 & 29.2 \\
\hline Once in six months & 36 & 30.0 \\
\hline Once in a year & 24 & 20.0 \\
\hline Don't travel at all & 2 & 1.7 \\
\hline Type of marriage & 23 & 19.1 \\
\hline \multicolumn{3}{|l|}{ Polygamous } \\
\hline Monogamous & 44 & 36.7 \\
\hline Estimated annual income & 76 & 63.3 \\
\hline \multicolumn{3}{|l|}{ Below $40,000.00$} \\
\hline $40,001-80,000$ & 47 & 39.2 \\
\hline $80,001-120,000$ & 10 & 8.3 \\
\hline $120,001-160,000$ & 16 & 13.3 \\
\hline Above $160,000.00$ & $\begin{array}{l}8 \\
39\end{array}$ & $\begin{array}{r}6.7 \\
32.5\end{array}$ \\
\hline
\end{tabular}

and have both home and community responsibilities.

About $54.2 \%$ are male while $45.8 \%$ are female which is an appreciable number implying that almost equal number of male and female rear sheep and goat in the area. This implies that both male and female should be carried along in the effort to develop the enterprise. About $68.0 \%$ of the respondents are married while $26.7 \%$ are single. Seventy-five percent of the respondents have formal education, about $64.2 \%$ had post primary level of education.

This implies that most of the respondents might likely have access to information on new technology and are likely to adopt such new technology. This was in agreement with the findings of Okunlola (2002) that reported that level of education influence adoption of technology as it gives opportunity for such adopters to be reached through many media. About $69.0 \%$ of the respondents who rear sheep and goat are involved in other occupations such as trading, civil service, farming and others. This implies that goat and sheep rearing is a secondary occupation most of the time to most respondents. This confirms Kaufman and Francis (1990) cited by Okunlola, 2002 assertion that structures of ownership of ruminants is very broad, they are kept as adjunct to the main business of cropping. About $67.0 \%$ of respondents are Christians while $30.0 \%$ practice Islamic religion. The implication of this finding is that goat and sheep rearing is not in conflict with any religion. Thirty-nine percent of the respondents earn N40, 000.00 annually while 31.0 percent of the respondents earn annual income above N160, 000.00. This implies that goat and sheep are not only reared by low income earners. 
Table 2: Frequency Distributio Respondents and Consumption of Goat and Sheep milk Frequency

Awareness

Aware 33

Not aware

87 n of Awareness and Sources of Awareness among

Percentages

27.5

72.5

Sources of awareness

Radio / television

Relative / friends

Health personnel

$\begin{array}{ll}17 & 6.7\end{array}$

Extension agents

No response

Consumption of goat and

sheep milk

Yes

No

14.2

85.8

\section{Source: Field survey, 2008 \\ Distribution of respondents by awareness and sources of awareness of sheep and goat milk consumption among the respondents}

Agricultural extension functions by disseminating information to clientele and it prepares them to a frame of mind that makes them adopt new technology. From Table 2, majority of the respondents $(72.5 \%)$ are not aware that sheep and goat milk can be consumed by human beings. Only $27.5 \%$ of the respondents are aware that goat and sheep milk can be consumed by human beings. About $14.2 \%$ of the respondents got their information about goat and sheep milk consumption from relatives and friends, followed by health personnel (6.7\%) probably during health education and during visit to the hospital to treat one of the diseases that goat and sheep milk can cure. Only $2.5 \%$ got the information through radio and television. The least was from the extension agents (1.7\%). Only $14.2 \%$ of the respondent indicated that they have consumed goat and sheep milk before. The low consumption can be traced to their low awareness. This finding is in line with the reports of Ogundiwin, (1997); Adewumi, (2001, 2008); Okeke et al, (2007) which reported the readiness of farmers to consume and even market the milk if they are well informed and encouraged.

Reasons for Not Consuming Goat and Sheep Milk by the Respondents.

Respondents (70.8\%)identified lack of awareness as the main reason for low consumption of goat and sheep milk. Also $95.8 \%$ of the respondents identified preference of other sources of milk as their reason for not consuming goat and sheep milk. Other reasons for low consumption of goat and sheep milk are the small quantity of the milk (14.0\%), odour $(12.5 \%)$, it is abomination $(18.3 \%)$ and it is not consumable (17.5\%). This is in agreement with Adewumi, (2001, 2008); Okeke et al (2007) who attributed militating against sheep and goat milk in Akure and Ibadan metropolis as lack of awareness, small quantity of goat milk being produced, lack of technical know how and stubbornness of goat.

Majority of the respondents preferred other sources of milk to sheep and goat milk implying that respondents are 
already used to other sources of milk which are well packaged. About $4.0 \%$ of the respondents are of the opinion that consumption of sheep and goat milk will make them behave like sheep and goat. The most discouraging factor hindering the consumption of sheep and goat milk is the animal behaviour; sheep are known to be stupid while goats are stubborn. Others are lack of milking technique (15.8\%) if information on sheep and goat reaches the farmer, it will increase farmers desire to know more, arouse their interest and motivate them to give a trial to the consumption.

Perception of the respondents on sheep and goat milk

Table 3 shows that many $(57.49 \%)$ of the respondents have positive perception of sheep and goat milk consumption thus, corroborating Adewumi, 2001 and 2008; Okeke et al 2007.

Table 3: Frequency Distribution of Reasons for Not Consuming Goat and Sheep Milk

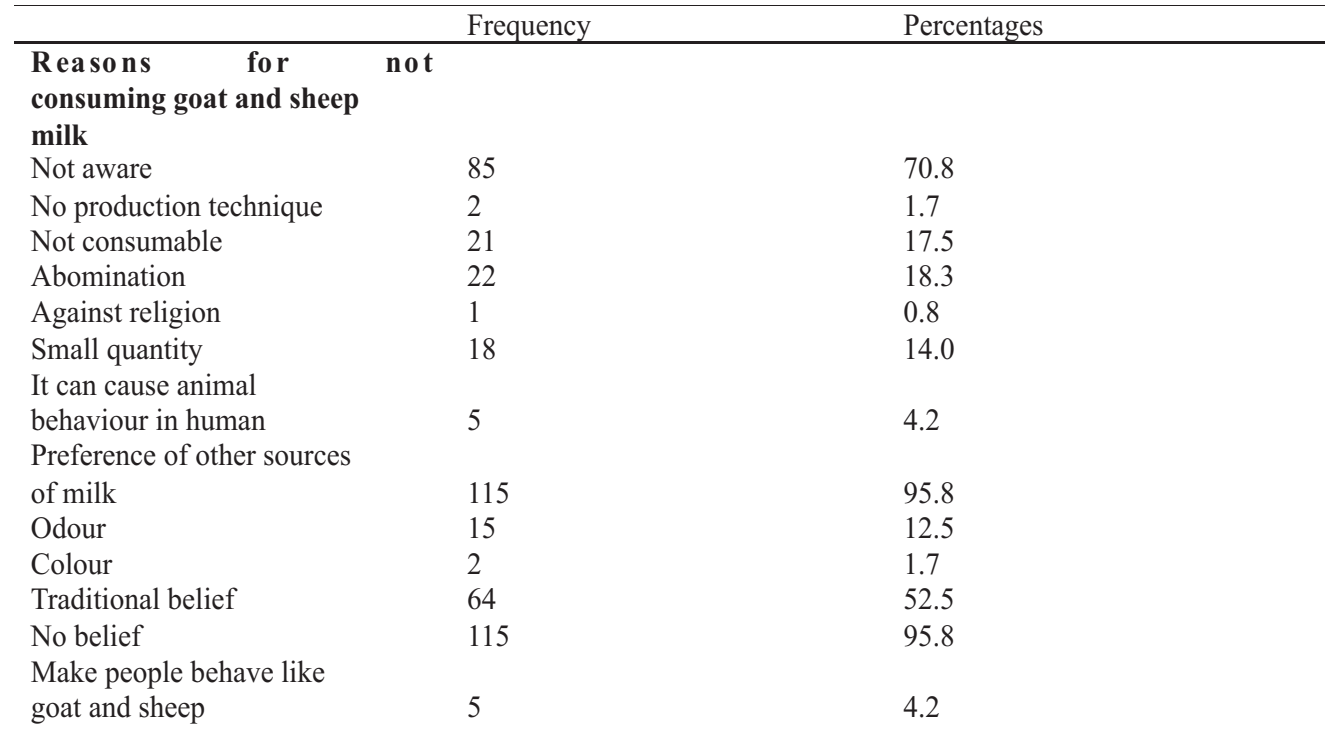

Source: Field survey, 2008 (Note: $\mathrm{N}$ is not equal to 120 due multiple responses from the respondents)

Table 4: Perception of the Respondents about Sheep and Goat Milk Consumption

\begin{tabular}{lll}
\hline Perceptional score & Frequency & Percent \\
\hline Negative (14-20) & 1 & 0.8 \\
Indifferent (21-28) & 50 & 41.7 \\
Positive (above 28) & 69 & 57.5 \\
\hline
\end{tabular}

Source: Field Survey, 2008 
Table 5a: Relationship between Socio-Economic Characteristics and Perception of the Respondents (PPMC test)

\begin{tabular}{lllll}
\hline $\begin{array}{l}\text { Independent } \\
\text { variables }\end{array}$ & $\begin{array}{l}\text { Dependent } \\
\text { variable }\end{array}$ & r-value & p-value & Decision \\
\hline Age & perception & 0.58417 & 0.0001 & Significant \\
Family size & $\begin{array}{l}\text { Perception } \\
\text { Income }\end{array}$ & 0.98751 & 0.0001 & Significant \\
& perception & -0.08011 & 0.3844 & Not significant \\
\hline
\end{tabular}

Source: Field survey, 2008

Table 5b: Relationship between Socio-economic Characteristics and Perception the Respondents (Chi-square test)

\begin{tabular}{lllll}
$\begin{array}{l}\text { Independent } \\
\text { variables }\end{array}$ & $\begin{array}{l}\text { Chi-square } \\
\text { value }\end{array}$ & DF & p-value & Decision \\
\hline Marital status & 131.87 & 3 & 0.0003 & Significant \\
Education & 25.584 & 4 & 0.0001 & Significant \\
Cosmopolitanism & 50.30 & 5 & 0.0001 & Significant \\
\hline
\end{tabular}

Source: Field survey, 2008

While only $0.8 \%$ of the respondents have negative perception of the milk. About $41.7 \%$ of the respondents are indifferent about the milk. This implies that if respondents are well informed, they may likely have positive perception about the consumption of the milk.

There was significant $(\mathrm{p}<0.05)$ relationship (Tables 5a and $\mathrm{b}$ ) between the socio-economic characteristics such as age $(\mathrm{r}=0.58417, \mathrm{p}<0.05)$, family size $(\mathrm{r}$ $=0.98751, \mathrm{p}<0.05)$ marital status $\left(X^{2}=\right.$ $131.87, \mathrm{p}<0.05)$ education $\left(X^{2}=25.584, \mathrm{p}\right.$ $<0.05)$ and cosmopolitanism $\left(X^{2}=\right.$ $50.300,0.05)$ and perception of the rural dwellers about sheep and goat milk consumption. However, no significant $(p>0.05)$ relationship exist between income and perception of the respondents. This implies that the perception is not ruled or controlled by socio-economic status of the respondents. This implies that if people are properly informed about the milk, it can be consumed by the rich, the poor and even the people with average socio-economic status.

\section{Conclusion}

In conclusion, sheep and goat milk is an important animal protein source which contains almost all the minerals that the body needs to grow and function well. Most households in the rural area have at least one member rearing either goat or sheep or both. This means goat and sheep milk can be a cheap source of animal protein to the rural dwellers. The result of the study showed that most of the rural dwellers are not aware of consumption of goat and sheep milk. Information about the consumption of goat and sheep milk reached the respondents through friends, relatives and health personnel. Many of the respondents have never consumed goat and sheep milk. The factors that discourage people from consuming goat and sheep milk are the lack of awareness, the odour of the milk, traditional belief, preference of other sources of milk and its small quantity. Many of the respondents have positive perception about the milk and many feel indifferent due to their lack of awareness of the consumption of the milk. Of all the socio-economic characteristics considered in the study, 
age, family size, cosmopolitanisms and educational qualification have significant relationship with the perception of goat and sheep milk consumption. On the other hand, income of the respondents does not have significant relationship with their perception. This implies that if the milk is properly packaged, both the rich and the poor can consume it.

\section{Recommendation}

From the forgone study, the following recommendations emanate; there should be vigorous awareness campaign by stakeholders on the consumption of goat and sheep milk using mass media such as radio, television and news paper as respondents in this study are willing and ready to consume sheep and goat milk. Also, there should be workshops organized at each of the Local Government areas to train the participants on how to manually milk the animals and the processing of the milk to various products like cheese, yoghurt and butter. Government should make a policy to provide conducive atmosphere to the introduction of locally produced cheap substitutes of sheep and goat milk and change people's orientation to accept and consume sheep and goat milk as done in many other parts of the world.

\section{Acknowledgement}

Miss Adenike Racheal Oni is acknowledged for painstakingly collecting data for this study. Her patience, endurance and hand work is hereby appreciated.

\section{References}

Adewumi,0.O. Ologun, A.G. and J.A.Alokan 2001. Sensory evaluation and marketability of sheep milk in Akure. Journal of Agriculture, Forestry and Fisheries. 2:5-7.
Adewumi,0.0. 2008. Socio-economic factors influencing milk consumption pattern in some selected local government areas of Ekiti State. Applied Tropical Agriculture. 12:6-10.

Adewumi,0.O., Ologun, A.G and J.A.Alokan 2005. Milk yield, chemical constituent and stage of lactation in sheep. Procoeeding of the $10^{\text {th }}$ Annual Conference of Animal Science Association of Nigeria (ASAN). Sept. $13^{\text {th }}-16^{\text {th }} 2004$. University of Ado-Ekiti, Nigeria 240-241.

Aletor, V.A.1983. Implications of lima bean anti-nutritional factor for digestion, nutrient utilization and physiopathology of the rat. Unpublished Ph.D. thesis, Department of Animal Science, University of Ibadan.

Buffano, G., Dario, C., Laudadio, V. 1996. In, International Symposium, somatic cell milk of small ruminant. R. Rubino, ed, Bella, Italy, September 25-27, Wageningen Pers, EAAP, Publication No, 77. Pg 301304.

Daniluk, R.H.N. 2007. The wonders of sheep milk discovered. Retrieved $\begin{array}{llll}f & \mathbf{r} & \mathbf{0} & \mathbf{m}\end{array}$ Shepherdgourmetdairy.com/revie ws.html-15k-. on $26^{\text {th }}$ of February, 2008.

FAO 1998. Women and Sustainable f o o d s e c u r i t y (www.fao.org/wacent/faoinfo/sust dev/ fsdirect/fsdoe001.html) retrieved on $6^{\text {th }}$ of March, 2008.

Mohammed, A. M. and Mohammed, A. Alkahnal (1989). Studies on camel and goat milk protein. Nitrogen distribution and amino acid composition. Nutrient Reports 
International. 2:251-357.

Okeke, E.N. J.M. Usman, J. Akoun, O.O. Akinola and E.C. Odozie (2007). Awareness of goat milk consumption in Ibadan metropolis. In Sustainability of the Livestock Industry in an Oil Economy. Proceeding. of the $32^{\text {nd }}$ Annual Conference of the Nigerian Society for An $\mathrm{i}$ mal Production.Calabar, March 18-21. Ed Agiang, Agwunobi and Olawoyin. Pp 395-397.

Okunlola, J.O. 2002. Socio-economic factors affecting large scale goat and sheep production in Ogun State. Proceeding. of the 27 $7^{\text {th }}$ Annual Conference of the Nigerian Society for Animal Production. March 17-21, Federal University of Technology, Akure, Nigeria. Editors: V.A. Aletor and G.E. Onibi 355-358.

Ogundiwin, J.O 1977. Introducing goat milk for human consumption in Nigeria. Proceeding of the launching and First Annual Dairy Conference. Department of Food Science and Technology, University of Ife, IleIfe, Nigeria. 1: 146-150

Kaufman and Frances (1990). Cited in J.O.Okunlola (2002). Socioeconomic factors affecting large scale goat and sheep production in Ogun State. In: Increasing Household Protein Consumption through Improved Livestock Production. Proceeding of the $27^{\text {th }}$ Annual Conference of the Nigerian Society for Animal Production. March 17-21, Federal University of Technology, Akure, Nigeria. Editors: V.A. Aletor and G.E. Onibi 355-358.

Park, Y.W, M. Juárez, M. Ramos and G.F.W. Haelein (2007). Physicochemical characteristics of goat and sheep milk. Journal of Small Ruminant Research 68: 88113.

Wilson, R.T. (1984). Cited in J.O.Okunlola (2002) Socioeconomic factors affecting large scale goat and sheep production in Ogun State. In: Increasing household protein consumption through improved livestock production. Proceeding. of the $27^{\text {th }}$ Annual Conference of the Nigerian Society for Animal Production. March 17-21, Federal University of Technology, Akure, Nigeria. Editors: V.A. Aletor and G.E. Onibi 355-358 